\title{
SoM Krisztián* \\ A magyar állami vezetők hivatalos légiútjait megvalósító szervezetek 1950-1989
}

(Organizations and tasks of the official Hungarian airways departments of the Hungarian state from the mid 1950s to the end of the 1980s.)

\begin{abstract}
Absztrakt
A magyar állam vezetőinek hivatalos légiútjait lebonyolító szervezetek és feladataik változásai az 1950-e évek közepétől az 1980-as évek végéig.

Kulcsszavak:

Magyar Légiforgalmi Részvénytársaság , Magyar Légiközlekedési Vállalat , Magyar Néphadsereg Országos Légvédelmi Parancsnokság 89. Önálló Szállitórepülő Százada. ; Különleges Fontosságú Légiszállitások Főosztálya. ;

BM Kormányőrség Parancsnokságának Repülési Osztálya
\end{abstract}

\begin{abstract}
Changes of the organizations and tasks of the official Hungarian airways departments of the Hungarian state from the mid 1950s to the end of the 1980s.

Keywords:

Hungarian Air Traffic Company, Hungarian Aviation Company ; Hungarian People's Army National Air Defense Command 89. Independent Traveling Century. ; Special Aircraft Department of Special Importance. ; Air Force Department of the Interior Ministry Government Guardianship Headquarters
\end{abstract}

\footnotetext{
$*$

- Open Researcher and Contributor ID = Nyílt Kutató és Közremüködő Azonosító (ORCID) https://orcid.org/0000-0002-6993-2207.

Institutional attachements $=$ Szerzö intézményi kötődései :

- Bertalan Szemere Scientific Society of History of Hungarian Law Enforcement = Szemere Bertalan Magyar Rendvédelem-történeti Tudományos Társaság @: som.krisztian@hotmail.com doi: 10.31626/HU-EISSN2560094X.IV.TOM.133-144.p
} 
Ilamfő saját használatára szánt repülőgép első alkalommal 1936 szeptemberében állt szolgálatba Magyarországon. A Junkers Ju 52/3m típusú, különleges belső kialakítású repülőgép egyedi festéssel (függőleges vezérsíkján tölgy- és babérág keretezte magyar kiscímerrel) és a HA-DUR „beszélő” lajstromjellel került nyilvántartásba. nagybányai HORTHY Miklós kormányzó azonban mindvégig a vasutat részesítette előnyben a külföldi utazásai során is. Ebből eredöen e légi jármüvet 1938 őszén a Magyar Légiforgalmi Részvénytársaság (MALÉRT) átvette, majd új lajstromjellel forgalomba állította. Igény szerint, alkalmanként a magyar királyi kormány részére ezután is teljesített különutakat. ${ }^{1}$ A magyar kormánytagok külföldi útjukra, ha nem magyar repülögéppel vagy vonattal mentek, akkor esetenként a meghívó fél által küldött légi jármüvel utaztak.

A II. világháborút követően, az első években a magyar kormányküldöttségek légi utazásai általában szovjet, eseti jelleggel amerikai különjáratú repülőgéppel történtek. Idővel, a kormányzati légi utazásokat, a Magyar Néphadsereg 16. Önálló Szállítórepülő Század kötelékébe tartozó Liszunov Li-2 típusú légi jármüvel teljesítették, egészen 1956-ig. ${ }^{2}$

A magyar kormány megrendelésére gyártott Iljusin Il-14P típusú légi jármü 1956. V. 8-án érkezett Magyarországra. A HA-VLG lajstromjelü repülögép szolgálatba állitásával, bö másfél évtized után ismét megkezdődött a saját különrepülőgéppel kiszolgált kormányrepülések teljesítése.

A következő, második kormány-repülőgép Nyikita Szergejevics Hruscsov, a Szovjetunió Kommunista Pártja első titkárának ajándéka révén érkezett Magyarországra, 1957. V. 25-én. Az előzővel azonos típusú, HA-MAG lajstromjelü légi jármü kétszalonos kivitelezésű volt, $\mathrm{s}$ póttartályai segítségével a hatótávolsága meghaladta a 2200 km-t. (Az ilyen ajándékozás nem volt ritka a szovjet vezető részéről szocialista és fejlődő országok államfői, kormányai részére.) A HA-MAG, mint szovjet ajándék díjmentesen vételezhetett üzemanyagot a tököli katonai repülőtér szovjet alakulatától. Mindkét repülögép egyszerü oldalfestéssel bírt, felirat nélkül, a hátsó részen 
feltüntetett lajstromjelen kívül, a magyar zászlót viselte a függőleges vezérsíkon. ${ }^{3}$

$\mathrm{Az}$ állami külföldi légi utazások lebonyolítására a $\mathrm{BM}$ Kormányőrségen belül 1957-ben egy részleget hoztak létre, amelynek üzemeltetésébe került a légi jármú és a szükséges müszaki eszközök is. A BERÉNYI Lajos örnagy vezette alakulat állomáshelye a tököli repülőtér lett, annak is a repülőgépgyári része. A hajózó állományt döntően a Magyar Néphadsereg $(\mathrm{MN})$ légierejének kecskeméti alakulattól helyezték át, a kiszolgáló személyzetet a haderő és a Magyar Légiközlekedési Vállalat (MALÉV) munkatársai közül válogatták ki. Azonban, kezdetben mindkét magyar kormány-repülőgépet öttagú szovjet személyzet repülte, akiket majd csak 1959. elején váltott fel az Il-14-es típusra átképzett magyar állomány.

Ekkor történt meg a két Il-14-es átadása is a Magyar Néphadsereg részére. Ott megtörtént a repülőgépek átlajstromozása is: a HA-VLG-t 102-es, a HA-MAG-ot 512-es számmal vették új nyilvántartásba. Az 512-es repülőgép továbbra is a Belügyminisztérium (BM) Kormányőrség feladatszabása alapján teljesítette a külföldi utazásokat, döntően a ferihegyi repülőtérről.

A 102-es a Honvédelmi Minisztérium külügyi osztályán keresztül szervezett légi utakat bonyolította le. A 102-es számú repülőgépet 1960. július elején a MALÉV-hez helyezték át, ahol megtörtént annak a közforgalmi igényekhez igazodó belső átalakítása. A magyar légitársaság másfél évig, HAMAK lajstromjellel a közforgalmi útjain üzemeltette. Ezt követően, 1961. októberében a légi jármü visszakerült a kormányzati utakat teljesítő alakulathoz, amely — a szalonos berendezés visszaalakítását követően - átfestve, piros kettős csíkkal, magyar katonai felségjellel, és ismét 102-es számon üzemeltette. A két Il-14-es 1967-ben került az Magyar Néphadsereg Országos Légvédelmi Parancsnokságának (MN OLP) szállítókötelékébe, ekkortól a kormányzati különutazásokat már egy újabb repülőgéptípussal teljesítették. ${ }^{4}$

A magyar kormány már 1965. november végén határozatot hozott kormányzati igénybevételek céljára egy Tupoljev 
Tu-134-es repülőgép beszerzéséröl, ${ }^{5}$ de ez sokáig váratott magára. Végül 1967. decemberében került a Magyar Néphadsereg állományba az a két Antonov An-24V típusú, különlegesen kialakított szállító-repülőgép - 907 és 908 lajstromjelü -, amelyeket a kormányzati külföldi, és honvédelmi minisztériumi légi utazások teljesítésére rendeltek, előbbi feladat elsőbbségével. E légi jármüvek háromszalonos változatban kerültek kialakításra. Az An-24V-kel teljesített kormányzati repüléseket 1967. első napjától a Magyar Néphadsereg Országos Légvédelmi Parancsnokság (MN OLP) 1. Önálló Légvédelmi Rendészeti és Kommendáns Zászlóaljának (MN 7750/A jelzésủ) alegysége végezte. A müszaki és hajózó személyzet a megalakuláskor 85 fö́t számlált. A két Il-14-es továbbra is állományban maradt, $\mathrm{s}$ néhány évig a $\mathrm{BM}$ illetve MN OLP alárendeltségében repült. ${ }^{6}$

A nagyobb létszámú küldöttségek, illetve az 1960-as évek második felétől, az Európán kívüli kormányzati utak teljesítéséhez a Belügyminisztérium Kormányőrség a MALÉV középes (akár $4800 \mathrm{~km}$ ) hatótávú repülőgépeit, az Iljusin Il-18-as típust vették igénybe. Ezek révén magyar polgári légi jármü számos országba elsőként, több városba egyedüli alkalmakkal jutott el. Dél-Ázsia, Indokína, Észak-Korea mellett több alkalommal repültek különjáratot Afrika számos országába. A magyar légi jármüparkkal, a leszállás nélkül megtehető legnagyobb távolság korlátja miatt, egyedül az amerikai utak teljesítése volt megoldhatatlan eseti külföldi bérlés nélkül.

A kormányzati repülések esetén a Belügyminisztérium III/II. Csoportfőnökségétől kirendelt operatív tiszt feladatai közé tartozott a repülőgép müszaki állapotának ellenőrzése mellett az üzemanyag minőségének ellenőrzése is, mindezekről jegyzőkönyvet is készíteni kellett. Minden utazás esetén vizsgálni kellett a repülötér és létesítményeinek, biztosító leés felszállási berendezéseinek alkalmasságát is. A repülőgép ki- és hazautazása során a légifolyosót szükséges mértékig le kellett zárni; a levegőben tartózkodás során, a magyar államhatáron belül vadászrepülő kíséretet biztosítottak. ${ }^{7} \mathrm{~A}$ kiemelt magyar és külföldi állami utazások során, a repülötéri rendé- 
szeti feladatok ellátása 1969. elejétől a BM II/III-3. (Folyamés Légiközlekedési) Osztályának, majd 1973. nyarától a BM II/II Csoportfőnökség légirendészetének és repülőtéri őrsének feladata lett. Az osztály kijelölt állománya - együttmüködve a BM III/II-6. Osztály, a közlekedés megelöző védelmére rendelt kémelhárító szerv munkatársaival - vizsgálta át a ferihegyi felszállópályát, a gurulóutakat, az érintett gépállóhelyeket biztonsági szempontok szerint, továbbá a repülőtéri épületek tetejét, az illetéktelenek eltávolítása végett. Ezen túlmenően, kijelölt személy felügyelete a távol- és közelkörzeti légiforgalmi irányítás munkáját, és szükség esetén beavatkozhatott, döntést hozhatott a biztosított utazás biztonsága érdekében. Az említett szervezeti elem intézkedett, a repülőteret üzemeltető MALÉV útján, az igénybe vett forgalmi előtér kiürítéséről, illetve az üdvözlő tömeg részére kijelölt terület kordonnal történő lezárásáról is. A BRFK Ferihegyi Légirendészeti Tiszti őrse biztosította a leszállópálya végein felállított egy-egy őrszemet. ${ }^{8}$ A kisebb létszámú és alacsonyabb rangú, miniszteri szintü küldöttségek mindvégig, döntöen menetrend szerinti repülöjáratokon utaztak, biztosításuk is ennek megfelelően szerényebb volt. ${ }^{9}$

Az An-24V típusú repülőgépek üzemeltetését 1971. szeptember 1-én a MN OLP 89. Önálló Szállítórepülő Századának (MN 1936) kizárólagos felügyelete alá kerültek. A két Il-14est 1976. nyarán vonták ki a forgalomból. A katonai alakulat több átszervezésen és átnevezésen esett át, 1977. első napjától az alegység neve 93. Vegyes Repülőszázad lett. ${ }^{\mathbf{1 0}}$

A kormányzati utazások teljesítésére a MALÉV szervezetén belül — a Közlekedés- és Postaügyi Minisztérium és a Belügyminisztérium közös felügyelete alatt — 1970. XI. 1-jén felállították a Különleges Fontosságú Légiszállítások Főosztályát. A vonatkozó utasítás szerint a repüléseket Tu-134-es repülőgépekkel kellett teljesíteni, de a hosszú távú különjáratokhoz továbbra is a kedvezőbb hatótávolságú Il-18-as típust vették igénybe. A különjáratok személyzetét a BM III/II. Csoportfőnökség (állambiztonsági szolgálat külső elhárításának) egyetértésével, jóváhagyásával a MALÉV biztosította. A kor- 
mányzati utazások mindenre kiterjedő megszervezése, és végrehajtásának felügyelete a kormányőrség feladata volt, amely emellett biztosította a fóváros és a repülőtér közötti közlekedést, és a ferihegyi kormányzati várótermet is. Ez 1971. VIII. 16-tól annyiban változott, hogy az utazások a közölt igényeknek megfelelő megszervezését és az utazók ellátását a MALÉV vette át. ${ }^{\mathbf{1 1}}$

Közel egy év múlva újabb átszervezést hajtottak végre. Ekkor — a Különleges Fontosságú Légiszállítások Főosztályának egyidejü megszüntetésével — a BM Kormányőrség Parancsnokság szervezetén belül, 1972. szeptember 1-jén felállították az V. [Repülési] Osztályt, amely hajózó személyzetét a MALÉV-tól és a Néphadseregtől helyezték át. Ez az új egység átvette a kormányzati repülések valamennyi, addig az MN és a MALÉV által végzett tevékenységét. Ennek érdekében még abban az évben áthelyezték a magyar légitársaság két Tu134-es repülőgépét, amelyek egyedi festéssel repültek a következő év elejétől. Ezeket az 1974. augusztusi saját beszerzés után, októberben visszaadták a polgári légiközlekedési vállalatnak. ${ }^{12}$ A BM Kormányőrség hajózó személyzete, valamint földi és légi utaskísérői rendszeresített polgári munkaruhában teljesítettek szolgálatot, amelyet részükre biztosítottak. Ez 1980 . végén annyiban módosult, hogy az immár megegyezett a MALÉVnél alkalmazottakkal. ${ }^{\mathbf{1 3}}$

A BM Kormányőrség főpilótájának BAKCSI Miklós kormányőr alezredest - korábbi néphadseregbeli légijármü vezetőt - nevezték ki, aki e tisztet a légi szerencsétlenség miatt, 1977. őszén bekövetkezett haláláig betöltötte. ${ }^{\mathbf{1 4}}$ A kormányőrség repülőgépeivel — a 3.000 km-es, leszállás nélküli hatótávolságuk okán — döntően a magyar állami és politikai vezetők Európán belüli utazásait bonyolították le, azonban ritkán a hosszújáratú utazásokhoz is ezeket vették igénybe, közbeiktatott müszaki leszállásokkal. ${ }^{15}$ Alkalmanként, a kormány vagy az állampárt által meghívott külföldi vendégeket is szállították az egyedi módon berendezett kormányzati légi jármúvekkel. ${ }^{\mathbf{1 6}}$

A biztosított állami utazás megkezdése előtt, a müszaki állapot ellenőrzésén túl a repülőgéppel berepülést is végre kellett 
hajtani. Az ellenőrzések továbbra is kiterjedtek a ferihegyi területek felügyeletén túl, az üzemanyag minőségének vizsgálatán és a tartalék áramforrás biztosításán át, a repülötéri szerveknél folytatott operatív tevékenységig. ${ }^{17}$

A BM Kormányőrség főtiszti és tiszti rendfokozatú repülőgép-vezetői, navigátorai és hajózó szerelői már az 1970-es évek közepén számos alkalommal, de eseti jelleggel a MALÉV Tu-134-es típusával repült menetrend szerinti utasjáratain is szolgálatot teljesítettek, hogy repülési ismereteiket szinten tartsák, fejlesszék. Azonban ezt sosem hajtották végre MALÉV-kormányőrségi vegyes repülőgép-vezető személyzettel. Ilyen repülésekkor a repülőgép minden esetben a MALÉVé volt, mivel ezek viselték a polgári légiforgalomhoz szükséges azonosító jeleket és a légitársaságra utaló jelzéseket. ${ }^{18}$

A nagyobb létszámú, hosszútávú kormányzati járathoz 1973 után általában már a MALÉV Tupoljev Tu-154-es repülőgépeit és annak személyzetét vették igénybe. Ezek 850 $\mathrm{km}$ /óra sebességre és akár $4800 \mathrm{~km}$ leszállás nélkül történő megtételére voltak alkalmasak. A tartalékszemélyzettel és a távoli helyszínekre repülőszerelőkkel megerősített hajózó állomány parancsnokai mindig a magyar légitársaság oktató kapitányai (vállalati föpilóta, típus-föpilóták és helyetteseik) voltak. Különösen azon utak igényeltek hosszas elökészületeket, szervezést, ahol magyar repülőgép még nem járt, vagy a legutóbbi alkalom óta hosszú idő telt el. Ekkor a repülőtér adottságairól, megközelítéséről, tartalék leszállóhelyekről kellett a lehető legtöbb szükséges adatot összegyüjteni. Az államvagy kormányfö külföldi útjain néhány fös kormányőrségi biztonsági őrség is utazott. ${ }^{19}$ Ilyen utak során magyar légi jármü először szállt le — többek között — a Fülöp-szigeteken, Japánban és Közép-Afrika számos államában is.

A MALÉV Isztambul-Bukarest-Budapest (MA-203-as számú) útvonalát teljesítő HA-LBC lajstromjelű Tu-134 típusú repülőgépe 1977. IX. 21-én, négyfős kormányőrségi hajózó személyzettel a bukaresti repülőtér megközelítésekor katasztrófát szenvedett. Ennek oka részben az volt, hogy az adott útra beosztott repülőgép a BM Kormányőrségénél repülttől régebbi 
volt, s a repülőgépvezetők annak sajátosságait nem ismerték kellően. ${ }^{20}$ Ezt követően a belügyminiszter intézkedett, hogy a BM Kormányőrség hajózó és müszaki személyzetét folyamatosan gyakorlatban tarthassák. E célból a Közlekedés- és Postaügyi Minisztériummal (KPM) és a MALÉV-vel történő együttmüködési megállapodás kidolgozására utasította az illetékes parancsnokot. ${ }^{21}$

A két kormányzati repülögép polgári lajstromjellel és MALÉV-festéssel történő ellátásáról 1979 augusztus végén adtak ki utasítást. A repülőgépek állami tulajdonban maradtak, azonban a légialkalmassági és egyéb iratokban a MALÉV-et szerepeltették tulajdonosként. A különleges utazásokat ekkortól kezdve polgári repülések közé sorolták, azonban a szervezés és a végrehajtás továbbra is a BM Kormányőrség hatásköre és kötelessége maradt. Ugyanekkor az előre kidolgozott és meghatározott együttmüködési megállapodások is aláírásra kerültek a két érintett fél, a kormányőr parancsnok és a magyar légitársaság vezérigazgatója között. Ezek a MALÉV részére számos többletfeladatot eredményeztek, amelyek ráadásul számos esetben elsőbbséget élveztek saját müködésével szemben. A hajózó személyzet szinten tartása (,gyakorlatban tartó repülések") érdekében őket ekkortól, előzetes terv alapján be kellett osztani a magyar légitársaság nemzetközi járataira is. ${ }^{22}$

A repülések napját és az abban részt vevő személyzet öszszeállítását a Kormányőrség határozta meg havi bontásban, amelyet a MALÉV Repülés Tervezési Osztálya ütemezett be. Amennyiben a kellő létszámú kormányőr hajózó nem állt rendelkezésre, akkor a magyar légitársaság azt pótolni volt köteles. A Kormányőrség állományába tartozó, de MALÉV útvonalat MALÉV egyenruhában teljesítő személyzet részére a vonatkozó napokon a napidíjat a légitársaság fizette. A kormányzati repülések külföldi repülési engedélyeit ekkortól a MALÉV Kereskedelmi Osztályának kellett a Kormányőrség kérelmére megigényelnie. Ugyanígy a BM Kormányőrség és a KPM Légi Rendészeti Igazgatóság (LRI) között is megállapodást írtak alá, amely elsősorban a VIP-101-es (kormányzati felsővezetők) utaztatásához kapcsolódó feladatokat (ideiglenes 
zárlatok rendjét és arról történő értesítési listát) határozott meg. ${ }^{23}$

A BM Kormányörség V. [Repülési] Osztálya 1987. XII. 31-vel megszünt, két repülőgépét és a kormányzati utasszállítás végrehajtását a MALÉV vette át (vissza), ezt követően is különjáratok, és később esetenként menetrend szerintiek révén teljesítve azt. Azonban a HA-LBR lajstromjelü Tu-134A típusú repülőgép továbbra is az esetleges kormányzati utazások teljesítésére volt kijelölve (egészen 1994-ig; utolsó kormányzati útját 1994 . VII. 18-án repülte). ${ }^{24}$

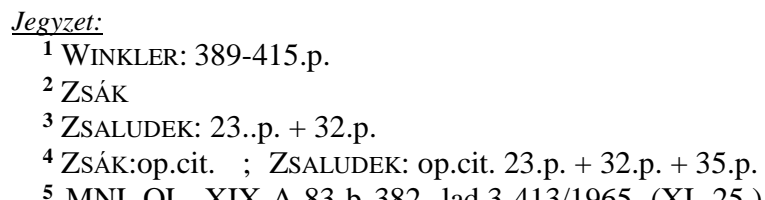

5 MNL.OL. XIX-A-83-b 382. lad.3 413/1965. (XI. 25.) Korm. hat. kormányzati célokra repülőgép és motorvonat beszerzéséröl.

6 ZsÁK: op.cit.

7 ÁBTL. 4.2.-10-21/21/1967. 021/1967.BM.pcs. tárgy nélkül.

8 - ÁBTL 4.2.-50-8/2/1969. BM.II/III csoportfőnök végrehajtási utasítása a belügyminiszter elvtárs 021/1967. BM. számú parancsának végrehajtása közúti, vízi és légi utazások esetén.

- ÁBTL. 4.2.-50-8/7/1973. BM.II/II csoportfőnök végrehajtási utasítása a Belügyminiszter Elvtárs 026/1972. (XII.27.) parancsához. A párt- és állami vezetők, delegációk utazásainál a biztosítási feladatok végrehajtásának szabályozása.

${ }^{9}$ Magyar kormányküldöttség érkezett Moszkvába.

10 ZsÁK: op.cit.

11 - ÁBTL. 4.2-10-22/2/1971. 02/1971.BM.ut. a „különösen fontos” légi utazások szabályozása.

- ÁBTL. 4.2.-sz.n. 0022/12/1971. (VIII.14) KPM-BM együttes utasítása a kormányzati légi utazások megszervezéséről és végrehajtásáról.

12 A MALÉV HA-LBG és HA-LBH lajstromjelü légi járművét, az átfestésüket követően - immár HA-924-es és HA-925-ös számmal - kormányőr személyzet repülte. (Ezek a BM Kormányőrség kötelékében 1.117 felszállás során összesen 1.259 órát repültek) A két repülőgépet 1974-ben váltották le a BM Kormányőrség megrendelésére készült Tu-134A típussal. Ezek kezdetben a HA-926 és HA-927 lajstromjelet viselték, majd a későbbiekben azokat a nemzetközi elöírásokhoz igazodó HA-YSA, illetve HA-YSB nyil- 
vántartási számmal látták el. E repülőgépeket 1981. tavaszán váltotta le az azonos típusú HA-LBP és a HA-LBR lajstromjelü légi jármủ, amelyeket azonban már MALÉV-festéssel látták el (előbbi szalonos volt, míg utóbbi közforgalmi vagy szalonos elrendezésű is lehetett), de tulajdonosa ezúttal is a kormányőrség volt. Ez utóbbi repülőgép-pár a kormány szolgálatában 4 232 felszállás során összesen 7071,5 órát repült.

ZAINKÓ - ZSALUDEK: 15.p. + 23-31.p.

13 - ÁBTL. 4.2.-10-22/22/1975. 22/1975.BM.ut. a BM Kormányőrség Parancsnokság Repülési Osztálya beosztottjainak munkaruha ellátása.

- ÁBTL-4.2.-10-21/1/1981. 1/1981.BM.ut. a BM Kormányőrség Parancsnokság Repülési Osztályán szolgálatot teljesítők ruházati ellátásának módosításáról.

${ }^{14}$ Búcsúzóul. ; ZAINKÓ - ZsALUDEK: op.cit. 15.p.

${ }^{15}$ ZAINKÓ - ZsALUDEK: op.cit. 13.p. + 15. + 23-31.p.

${ }^{16}$ Luis CoRvalÁN chilei kommunista politikus az MSZMP Központi Bizottságának meghívására, a magyar kormány-repülőgépen érkezett Budapestre.

Luis Corvalán hazánkba érkezett.

17 ÁBTL. 10-21/26/A/1972. 026/1972.BM.pcs. végrehajtási utasítása.

18 Búcsúzóul: op.cit. ; SZABÓ: 465.p. ; ZAINKÓ - ZSALUDEK: op.cit. 15.p.

19 BARACS

${ }^{20}$ SZABÓ: op.cit. 465. p.

${ }^{21}$ Egyúttal intézkedés történt, hogy a Kormányőrség hajózó állománya a MALÉV azonos beosztású tagjainál $20 \%$-kal magasabb jövedelmet kapjanak. Továbbá az egyéb beosztásúak jövedelme is a magyar légitársaságnál kedvezöbb mértékben alakult.

ÁBTL-4.2-10-21/18/1978. 18/1978.BM.ut. a kormányrepülőgépek és a ferihegyi kormányvárótermek igénybevételének szabályozásáról.

${ }^{22}$ Vélhetően hatékonyabb lehetett volna a gyakorlatszerzés, ha a kormányőrök nem csak adott járatok teljes személyzetét adják, hanem időrölidőre MALÉV személyzet egy-egy tagjaként, póttagjaként (repülőgépvezetőként, fedélzeti szerelőként, stb.) is repülnek.

${ }^{23}$ ÁBTL. 4.2-10-37/1/19791/1979. BM-KPM.ut. a kormányrepülőgépek üzemeltetéséröl, valamint a kormányzati légi utazási feladatokról.

${ }^{24}$ ZAINKÓ - ZSALUDEK: op.cit. 15.p. ; 31.p. 
Forrás- és irodalomjegyzék (a jegyzetekben alkalmazott röviditések oldása): MONOGRÁFIÁK KISMONOGRÁFIÁK ÉS HASONLÓ JELLEGÜ KÖTETEK

SzABÓ

$(18 . ; 20 ;)$

\section{TANULMÁNYOK}

WINKLER

(1.;)
WINKLER László: A Magyar Légiforgalmi Rt. története 1928-tól 1945-ig. 389-415.p. In CzÉRE Béla (szerk.): A Közlekedési Múzeum Évkönyve, VII. köt. (1983-1984) p. Budapest, 1985, Közlekedési és Dokumentációs Vállalat. 693 p. HUISSN 0133-4646.

\section{TÍPUSISMERTETŐK}

ZAINKÓ - ZSALU- DEK

(12.;14.;15.;18.;)

ZAINKÓ Géza - ZsALUDEK Endre: Tupoljev $T U$-134. Budapest, 2010, Magyar Repüléstörténeti Társaság. 72 p. HU-ISBN 9789638864628.

ZSALUDEK

$(3 . ; 4 . ;)$

ZsAludeK Endre: Iljusin Il-14. Budapest, 2013, Magyar Repüléstörténeti Társaság. 68 p. HU-ISBN 9789638864666 /Aero História, 6./ HU-ISSN 0238-7905.

\section{CIKKEK}

Búcsúzóul.

(14.;18.;)

Búcsúzóul. Szerkesztőségi közlemény. Határör, XXXII.évf. (1977) 41.sz. 3. p. HU-ISSN 1419-5380.

Luis Corvalán hazánk- — Luis Corvalán hazánkba érkezett. Petöfi Néba érkezett. pe, XXXII.évf. (1977) 116.sz. (május 19.) 1.p. (16;) HU-ISSN 0133-235X.

Magyar kormánykül- - döttség érkezett Moszk-

Magyar kormányküldöttség érkezett Moszkvába. Szerkesztőségi közlemény. Petőfi Népe, XVI.évf. (1961) 178.sz. (július 30.) 1.p. HU-ISSN 0133-235X.

vába.

ZsÁK

ZsÁK Ferenc: Kormánygépek, kormányzati repülé(2.;4.;6.;10.;) sek. (A Magyar Néphadsereg repülöalakulatai, 21. rész) AERO magazin, XVIII.évf. (2016) 8.sz. (augusztus) 60-63.p. HU-ISSN 1419-4074. 
BARACS - - BARACs Dénes: A különgép. Szolnok Megyei (19.;) Néplap, XXXV.évf. (1984) 288.sz. (december 8.) 6.p. HU-ISSN 0133-0756.

\section{LEVÉL- IRAT ÉS DOKUMENTUMTÁRAK}

ÁBTL

ÁBTL (Állambiztonsági Szolgálatok Történe(7.;8.;11.;13.;17.; ti Levéltára).

21.;23.;)

MNL.OL.

(5.;)

MNL. (Magyar Nemzeti Levéltár) OL. (Országos Levéltár).
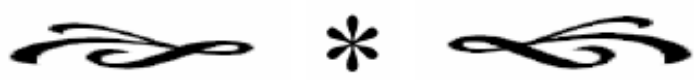